\title{
Exploring Conflict Management Strategies among School Administrators: A Case Study of an International Islamic School in Malaysia
}

\author{
Moussa Khaireh Soubagleh \\ University of Djibouti \\ Djibouti \\ moussa_khaireh@univ.edu.dj
}

\begin{abstract}
As educational organizations, schools are vulnerable to experiencing conflict. Notwithstanding the views of many scholars in the existence of functional conflict in a formal organization like school setting, proper management of conflict is required to be established by school administrators in order to ensure the smooth running of the school. The aim of this study was to explore the understanding of sources of conflict and conflict management among Islamic school administrators with the aim of formulating practical and effective strategies in conflict management within the school setting. The researchers used the qualitative case study method to explore the strategies adopted by three Islamic school administrators in handling conflict. The findings show that individual differences, commodification of education, school system and policy, human resource issues and practices, and attitude were the main factors giving rise to school conflict, while depression was identified as its resulting effect. The school needs to build trust, respect, stability, and teamwork into its atmosphere, culture and practices in order to prevent misunderstanding and conflict within its community.
\end{abstract}

Keywords: Conflict management, functional conflict, dysfunctional conflict, Muslim administrators, Islamic schools, Islamic administration

\section{INTRODUCTION}

The nature of educational institutions is that they deal with human interactions on a daily basis-be it teacher-student, teacher-teacher, teacher-parent, administrator-parent, teacheradministrator, and most certainly, student-student interactions. While establishing these interactions and relations, it is natural for educational practitioners to be exposed to varied and differing values, views, beliefs, traits, perspectives and practices which are contradictory in nature. Conflict is inevitable, and plagues all organizations. However, what makes the difference is how the conflict is managed by the institution. As educational bodies, schools are accountable for their organizational inputs which are positively related their organizational behaviours. Thus, educational administrators must treat conflict management issues with utmost importance because it is perhaps the most powerful tool for bringing about changes in the patterns of organizational behaviour (Hanson, 1996).

Common conflicts occurring in school may range from quarrels between the elements of the institution to physical abuse. It may be due to personal ambition, or even differences in opinion, or cultural backgrounds. The researchers decided to embark upon this study to explore the understanding of conflict management among school administrators with the aim of 
formulating practical and effective strategies in conflict management within the school setting. This study will fill in the empirical literature gap in conflict management within an Islamic educational setting. In addition, the findings will be a significant enrichment to educational practitioners as well as policymakers in education.

The fact that education has become a commodity and schools commercialized also creates a greater opportunity for conflicts to occur. In the current educational setup, parents are customers who pay money for services in the education of their children. As such, they have high expectations of such services, and reserve a right to complain in case there is dissatisfaction with the services. From an Islamic point of view, schools play a huge role in educating the ummah and in creating social order and cohesion. Given these roles, Islamic schools cannot afford to be ineffective. While they can never be free of crisis and conflict, the effectiveness of Islamic schools certainly cannot be reduced by their administration's poor conflict management. Therefore, it is critical to look into the conflict management strategies of Islamic school administrators. Given these observations, this study asked the following research questions: (i) What are international Islamic school administrators' views or perspectives on the sources/causes of conflict within their school management? (ii) How do Islamic administrators manage conflict within their school? (iii) What strategies do Islamic administrators practice in avoiding and managing conflict within the school?

\section{Theoretical Framework}

As suggested by Yin (2009), the use of a theoretical framework within a case study helps focus data collection and analysis. According to Rahim (2002), it is a consensus agreement among management scholars that there is no best approach in decision making and managing conflicts. Rather than creating a very specific model of conflict management, Rahim (2002) suggested creating a meta-model for conflict which is based on two dimensions, i.e., concern for self and concern for others. Within this framework, five management approaches were generated: integrating, obliging, dominating, avoiding, and compromising.

Integrating involves openness; transparency, exchanging information, looking for alternatives, and examining differences so solve the problem in an acceptable manner to both conflicting parties. Obliging refers to the attempt to minimize the differences and highlight the commonalities to satisfy the concerns of the opposing party. Dominating is associated with the style of one who goes all out to win his or her objective and, as a result, often ignores the needs and expectations of the other party. Avoiding refers to the act of evading failure by sidestepping an issue or withdrawing from a threatening situation. Avoiding is done to satisfy one's own concern as well as the concern of the opposing party. Lastly, compromising involves giving and taking, whereby both parties give up something to reach a mutually acceptable decision.

\section{Conflict Management}

The definitions of "conflict" have been given by various scholars in different spectrums of studies. The Learners' Dictionary simply puts it as 'being in opposition or disagreement," while Rahim, Garret and Buntzman (1992) views conflict as an interactive process manifested in incompatibility, disagreement, or difference within or between social entities (i.e. individuals, groups, organizations etc.). In many occasions, conflict is synonymous with violence; however, the United Nations International Children's Emergency Fund (UNICEF, 1995) denies that assumption, explaining that conflict occurs not only in situations of violence, but also when There are differences in ideas, values, positions, and perspectives on a range of issues. 
Conflict occurs along cognitive (perception), emotional (feeling), and behavioral (action) dimensions. Thus, with this three-dimensional perspective, we are helped to understand the complexities of conflict and its causes, which sometimes seem to proceed in contradictory directions. It is a never-ending debate among social theorists whether conflict is beneficial or unproductive. From a Deweyian perspective, for instance, conflict is an inevitable and healthy force of change. Thus, this view sees that conflict should occur in order to resolve disruption and be used as a creative force for positive change. Indeed, in some organizations, dissent is desirable and conflict resolution is used as a creative measure for positive change (Labich, 1988). In support of this view, Mc Namara (2007) argues that conflict is unavoidable and often good.

Models of functional conflict reflect the belief that all factions can achieve important organizational goals (Henkin, Cistone \& Dee, 2000; Deutsch, 1973), while destructive conflict perspectives assume interactions where one side must win and the other must lose (Burke, 1970). In agreement with scholars who support both functional and dysfunctional outcomes of conflict such as Weldon and Jehn ( 1995), Mitroff (1998), Pelled, Eisenhardt, and Xin (1999), Rahim (2002) states:

"What we need for contemporary organizations is conflict management and not
conflict resolution. Conflict management does not necessarily imply avoidance,
reduction, or termination of conflict. It involves designing effective macro-level
strategies to minimize the dysfunctions of conflict and enhancing the constructive
functions of conflict in order to enhance learning and effectiveness in an
organization." (p. 208)

It is very important to be aware of the distinction between conflict management and conflict resolution. While conflict resolution refers to resolving the dispute to the approval of one or both parties, conflict management refers to an ongoing process that may never end. Rahim (2002) narrates that several conflict management scholars, e.g. Amason (1996), Jehn, Northcraft, and Neale (1999), and Rahim (2001) have suggested the following strategies for managing conflict:

1) Conflict reduction, i.e. reducing conflicts that may have negative effects on individual and group performance. These conflicts are generally caused by the negative reactions of organizational members (e.g., personal attacks of group members, racial disharmony, and sexual harassment).

2) Generation and maintenance of a moderate amount of certain types of conflict. Certain conflicts have positive effects on the individual and group performance. These conflicts relate to disagreements relating to tasks, policies, and other organizational issues. The existence of these conflicts is good as they help to galvanize the institution in positive directions.

3) Constructive handling of conflict. Organizational members while interacting with each other will be required to deal with their disagreements constructively. This calls for learning how to use different conflict-handling styles to deal with various situations effectively.

Conflict management minimizes the negative outcomes of conflict and promotes the positive outcomes of conflict with the goal of improving learning in an organization (Rahim, 2002). Ma and $\mathrm{Yu}$ (2008) summarize their ten years of study on conflict management that literature focuses on three key themes: workplace conflict and conflict management styles, cultural differences in conflict management, and conflict management in practice. 


\section{Conflict Management in Schools}

Gumuseli and Hacifaciglu (2009) note that conflict is inevitable in schools since the ideas, aims, interests, and expectations of the stakeholders create the potential and much room for conflict. It is for this reason that administrators and teachers spend most of their time on managing conflicts. DiPaola and Hoy (2001) argue that understanding differences in issues that give rise to conflict and the relationships between conflict and change can help practicing administrators improve the climate in schools. Reports and studies have revealed that violence against teachers, other students, and destruction of property both in the learning institution and surrounding communities has greatly increased in the past years (Onsarigo, 2007).

Many school administrators seek to eliminate conflict because of its effects on the reputation by its association with psychopathology, social disorder, and war. This is due to the belief that many educational institutions are established only to foster cooperative human endeavor in order to achieve objectives that are unachievable individually, thus, educational institutions' ideals normatively emphasize cooperation, harmony, and collaboration (Owens, 1998). However, it is the root of personal and social change; it is the medium through which problems can be aired and solutions arrived at (Deutsch, 1991).

Conflict that typically occurs in the school setting may be categorized into three: (i) that between teachers and students; (ii) conflict between and among teachers, and (iii) conflict between teachers and parents. It is undeniable that some conflicts work to improve school effectiveness, while some others do not bring about any positive influence. However, in handling conflict, the position of administrators should not be one of avoidance or disregard. Ignoring conflict may end up causing more harm to the institution as it is likely to affect the operations of school administration and teaching businesses negatively, or even spoil the interpersonal relationship between teachers and staff. It also violates the principles of fairness and justice, and may well hamper clear communication resulting in further misunderstanding and dissatisfaction. When conflict occurs, managers of the school should find ways of managing it properly so as to prevent the conflict from escalating and causing dysfunctionality within the school community (Kuo et al., 2014)

\section{METHODOLOGY}

\section{Context and Setting}

This was a qualitative case study conducted at a selected international Islamic school located in Kuala Lumpur. The qualitative case study method was used as the nature of the topic concerned an ongoing process involving dynamic human relations. The school was established in September 1998 as a result of years of study by Muslim scholars from various parts of the world who earlier taught at a local Islamic university. The scholars conceived of an integrated Islamic school model that could address the educational needs of Muslim children, hence providing an education avenue for the diverse Muslim community and expatriates. The creation of the school was thus a testimony to the Islamic university's continuous effort in providing quality, affordable, balanced, integrated and holistic education guided by the principles of Islam. It has grown from a humble beginning of 30 students to an enrolment of approximately more than 1000 students from 46 different nations ranging from primary to A-level studies. 


\section{Participants and Procedures}

Three informants from an international Islamic school were chosen: the incumbent principal, the school's former principal, and the current vice principal of academic. A reasonable degree of anonymity was assured for all study participants and that no unusual risks existed for any of them. The following steps were taken to protect their anonymity:

1) Voluntary, informed consent was obtained from all interviews;

2) Transcriptions were labeled by number, rather than by name;

3) Indicators that could identify the situation or participants were removed or changed; and

4) Coded transcriptions were secured and could only be accessed by the researchers.

The interviews were conducted and audio recorded. The data from the interview were transcribed in verbatim form. The process of coding generated themes that constituted the study's findings.

\section{RESULTS AND DISCUSSION}

Through semi-structured interviews, the researchers were able to come up with themes that answered the research questions. Five themes led us to an understanding of the sources of conflict occurring in the school. They are: (i) differences among the individuals involved, (ii) commodification of education and the school, (iii) school system and policy, (iv) HR-related issues, and (iv) attitudes of all parties. The sixth theme that emerged, i.e. depression, is the result of the crisis that built up and was not successfully resolved. In the course of the interviews, the informants mentioned important values and strategies in the management of conflict such as building trust, respect, stability, equity, and teamwork.

\section{Administrators' Understanding of Causes of School Conflict}

In explaining their understanding of conflict management, all informants revealed what they thought to be sources of conflict that occurred in their school. The study has categorized the sources into seven main themes, namely (i) differences as causes of conflict, (ii) commodification, (iii) school system and policy, (iv) HR-related, (v) attitudes, and (vi) depression.

\section{Individual Differences}

Human beings are bound to experience conflict when they interact with one another. This is due to the fact that each human being has a different attitude and set of traits compared to another. These differences are also expected to happen in the workplace--Islamic schools are no exception. Informant A revealed that due to fact that different tasks are given to each individual, conflict is expected to arise, while informant $\mathrm{C}$ emphasized the differing interests among stakeholders. She said:

"Conflict in school occurs due to the different interests of stakeholders. Each stakeholder has his own perception of education and the benefit of education. (The way) how they look at education is different." [Informant C]

The fact that the existence of differences in goals and perceptions is one of the factors of conflict was also pointed by Pondy (1969) and Ramani and Zhimin (2010). 


\section{Commodification of Education and the School}

The theme of commodification was saturated when informants were asked to elaborate on their understanding of conflict, whereby two informants related the fact that the commodification of education plays a great role in creating conflicts within school settings. As a consequence of that commodification, the customer-and-service provider relation has been established in private schools nowadays. Thus, from the top management point of view, rationalization of the budget is very important in order to maintain the profits. At the other end of the issue, parents as paying costumers demand their money's worth. They want to see quality education being imparted. Informant B said:

"If the mission and vision of the school are on making more money definitely, there will be a conflict." [Informant B]

Related to the above theme, Gumuseli and Hacifaciglu (2009) have pointed out the effect of globalization and commodification which influences schools to be more aware of the needs and expectations of the economic and local powers, and parents. Parents' contributions and responsibilities in financing education led them to consider themselves as an authority that can interfere with the school administration. On commodification, Schwartzman (2013) asserts that the very concept of commodification encourages catering to students, pleasing them by minimizing challenges rather than equipping them to persevere in solving complex problems. Thus, when parents develop the mindset of having their children to be catered to as customers of schools, administrators feel intimidated and begin exerting pressure on teachers and staff, which in the end, could result in conflicts.

All informants were of the opinion that conflict is naturally inevitable, but it has to be minimized and made manageable. This is due to the fact that it is impossible to run away from conflict, as long as humans continue to interact and form interpersonal relationships. Using the view of functionalists, DeDreu (1997) argued that schools should have a minimum occurrence of conflict, no sense of urgency, no necessity to look for alternatives, and no incentives for conciliatory overtures.

\section{School Policy and System}

Two informants cited the school system and policy as sources of conflict in the school. Informant A criticized the admission policy which tends to accept all types of students into the school, which later develops into disputes among administrators, parents, and teachers. Informant $\mathrm{C}$ elaborated the difficulty of having too many hierarchies in the school, as many parents will shoot their complaints up to the General Manager or even to the Chair of the school, who according to the hierarchy, is higher in authority than the principal.

\section{Attitudes of Students, Parents, Teachers and School Administrators}

A very interesting opinion on one of the causes of conflict was discovered from Informant $\mathrm{C}$ who viewed that in many occasions, conflict arose due to the attitudes of students, teachers, administrators and parents. She said:

"Students may not be satisfied with the method of teaching of teachers, teachers may not be pleased with the attitude of students, parents may not be pleased with teachers, and teachers may dislike the attitude of parents, (and) In addition, teachers may dislike the school administrators' style, and the school head may be at war with the (top) management and vice versa." [Informant C] 


\section{Human Resource Issues}

The most common source of conflict lies in the issues related to human resource, such as salary increment, promotion, demotion, and so on which are considered very sensitive issues. Many assumptions have been leveled against the administrators, due to the absence of transparency in deciding factors pertaining to salary increment, as Informant A elaborated:

"There were teachers, who thought that I favoured the sciences and Maths teachers than the humanities teachers, so every year I give more increment to them." [Informant A]

\section{Depression}

Conflict that occurs in a school setting is often serious in nature as it affects the performance of teachers, and tarnishes the reputation of the school if it goes unmanaged. Teachers, at the end of this circle, will be victimized as depression brought about by the conflict will be a common symptom among them.

Dijkstra et al. (2005) and Yang and Mossholder (2004) report that employees who engage in task- or job-related conflict feel frustration, anger, and irritation, and are less satisfied with their jobs. No matter what the conflict is, whether it is relationship or task-related in nature, it tends to have prolonged negative effects on the affective dimension of humans (Gil et al., 2005). In addition, conflict affects the accomplishment of organizational goals due to attention being digressed to attending stress, hostilities, and other undesirable factors when conflict is poorly managed (Okotoni \& Okotoni, 2003).

\section{School Administrators and Conflict Management}

About the ways the administrators manage conflict in the school, two themes were saturated, namely transparency and monitoring. On transparency, Informant A elaborated that he tried to be as transparent as possible, especially when it concerned terms and conditions of employment, increment, and job distribution.

This agrees with the conflict management style of integrating proposed by Rahim (2002) which should involve openness and transparency. It is very important to be transparent, especially in terms of job distribution and remuneration, as modern organizations are required to practice transparency.

Mellander (as cited in Forssbaeck and Oxelheim, 2014) adds that transparency should be practiced in the dimensions of efficiency and equity, input utilization, skills and competencies, the dimensioning of education and the labour market, and finally, benefits and costs. Monitoring was the focus of Informant C, as she elaborated that to manage conflict, continuing to monitor teachers and staff is considered the key element to conflict prevention. As with thorough monitoring, suitable preventive measures such as discussion may be taken.

\section{Effective Management Strategies}

When exploring the administrators' perspective on the most effective strategies for managing conflict, the themes of building trust and respect emerged. 


\section{Building Trust Among All Parties}

Building trust should be done at all levels, be it between top management and the principal or between the principal and teachers and staff. The principal should be given more trust in terms of decision-making. In this Islamic school, the principal however was not the highest rank officer, as he or she should report to the senior manager and general manager, who in turn reports to the chair of the school. School administrators must also build trust so they are trusted by students and teachers, as well as parents. Informant $\mathrm{C}$ said:

"I think the first step is to build trust. They must be trusted by students, parents, and teachers. If you are not trusted, you will lose your integrity." [Informant C]

Tschannen-Moran and Hoy (1998) notes that trust is seen as a vital element in order to make an organization run and function properly. The existence of trust is necessary to maintain the effective co-operation and communication which are the bases for productive relationships (Baier, 1985).

\section{Cultivating Respect}

The second strategy is cultivating feelings of respect. It is very important to school administrators to earn respect from teachers, students as well as parents. To gain respect, good human relations need to be maintained. As Informant $\mathrm{C}$ stated, it is a must for school administrators to greet all people at school.

Besides greeting, protecting all the staff, both teaching and non-teaching, is the best way to earn respect from them. In this scenario, school administrators indirectly confirmed the value of every member of the staff of the school.

\section{Minimizing Conflict through Stability, Equality and Teamwork}

When all informants were asked about their opinions on the role of school owners or top managers in minimizing conflict, they come up with the themes of stability, equality, and teamwork. On stability, one of the informants said:

"The school owners must ensure a stable system. When they design policy on payment, promotion, staffing etc. they should stand by it and ensure that the policy they are formulating is fair and applicable to all irrespective of tribe, age or sex." [Informant A]

Blake and Mouton's (1964) two-surface theory established the importance of "assertiveness" and "cooperation" in conflict management. In assertiveness, the emphasis is on satisfying oneself, while in cooperation, the emphasis is on satisfying others.

In addition, school owners should maintain equity by removing any chance of favoritism and tribalism in their organizations. This is in agreement with the framework of intercultural respect by Egge (1999) who asserts that opportunities for advancement need to be applied across the board without regard to individualized issues such as gender, race, age, and others. Using the concept of equality of opportunity proposed by Roemer (1988), Mellander (as cited in Forssbaeck and Oxelheim, 2014) defines equity as equality of opportunity that an individual's educational and training outcomes should depend on her effort but not on her circumstances, i.e. family background, gender, and the like. For this reason, it would violate the principles of fairness and justice and block the way of communication, hence causing misunderstanding and dissatisfaction among important parties within the school community (Kuo et al., 2014). Finally, the informants stressed that the school owners must change their style of leadership, from pointing fingers at their subordinates to using a lot of teamwork management strategies. 


\section{IMPLICATIONS AND CONLUSION}

The findings of this case study suggest that five main factors gave rise to conflict in the school. They are: individual differences, commodification of education, school system and policy, $H R$-related matters, and attitudes of the relevant parties. As human beings are unable to avoid differences, the concept of respect towards individual differences should be established. As the Islamic school must accommodate people from different parts of the globe and live up to its name, the members of its community need to be more accommodating of cultural and individual differences. These differences will not go away; therefore, the school needs to find ways to manage the differences wisely and effectively.

Commodification happens in every aspect of education. Hence, the school must have the ability to adjust the balance of what international education services have to offer without losing the basic foundation of respect towards knowledge and its sources. Conflict cannot be minimized if members of the community have not adjusted themselves well with the system. Thus, a thorough orientation of the school's system and policies, as well as training the employees to develop a sense of belonging to the system, is very crucial in this issue.

As human resource services that include salary increment, staff benefits, and remuneration are very sensitive in nature, transparency on the part of school administrators should be very helpful in minimizing conflict among teachers, staff and the administrators themselves. If all the above-mentioned sources of conflict can be properly managed, a positive working atmosphere will prevail in the school. Such atmosphere helps produce a positive attitude among the community of staff and employees, which is very important in enhancing the school's effectiveness and performance.

Building trust, monitoring, and teamwork are the most effective strategies for managing conflict. Crisis may well be avoided if mutual trust is built between individuals, if a monitoring system to prevent conflict from escalating is maintained, and if teamwork management--that is not making organizational decisions without involving the management team--is practiced. If these conditions can be estblished, conflict that arises could be turned around to be functional and manageable. In addition, McCarthy (1981) suggests employing solution-oriented approaches to conflict management which allow the principal to play mediative roles and emphasize solution-finding through a consensual, cooperative process which avoids antagonisms that may endanger future personal and/or professional relationships. 


\section{REFERENCES}

Amason, A. C. (1996). Distinguishing the effects of functional and dysfunctional conflict on strategic decision making: Resolving a paradox for top management teams. Academy of management journal, 39(1), 123-148.

Baier, A. (1985). Postures of the mind: Essays on mind and morals. U of Minnesota Press.

Blake, R. R., \& Mouton, J. S. (1964). The new managerial grid: strategic new insights into a proven system for increasing organization productivity and individual effectiveness, plus a revealing examination of how your managerial style can affect your mental and physical health. Gulf Pub. Co..

Burke, R. J. (1970). Methods of resolving superior-subordinate conflict: The constructive use of subordinate differences and disagreements. Organizational Behavior and Human Performance, 5(4), 393-411.

DeDreu, C. (1997), "Productive conflict: the importance of conflict management and conflict issue", in DeDreu, C. and Van De Vliert, E. (Eds), Using Conflict in Organizations , Sage Publications, London.

Deutsch, M. (1973).The resolution of conflict. New Haven, CT: Yale University Press.

Deutsch, M. (1991). Subjective features of conflict resolution: Psychological, social and cultural influences. New directions in conflict theory, 26-56.

Dijkstra, M. T., van Dierendonck, D., Evers, A., \& De Dreu, C. K. (2005). Conflict and wellbeing at work: The moderating role of personality. Journal of Managerial Psychology.

DiPaola, M. F., \& Hoy, W. K. (2001). Formalization, conflict, and change: Constructive and destructive consequences in schools. International Journal of Educational Management.

Egge, S. A. M. (1999). Creating an environment of mutual respect within the multicultural workplace both at home and globally. Management Decision.

Forssbaeck, J., \& Oxelheim, L. (Eds.). (2014). The Oxford handbook of economic and institutional transparency. Oxford University Press, USA.

Gil, F., Alcover, C. M., Peiró, J. M., Medina, F. J., Munduate, L., Dorado, M. A., ... \& Guerra, J. M. (2005). Types of intragroup conflict and affective reactions. Journal of managerial psychology.

Gumuseli, A. I., \& Hacifazlioglu, O. (2009). Globalization and conflict management in schools. Cypriot Journal of Educational Sciences, 4(3), 183-198.

Hanson, E. M. (1996). Educational administration and organizational behavior. Allyn \& Bacon, A Simon \& Schuster Company, 160 Gould Street, Needham Heights, MA 02194-2310..

Henkin, A.B., Cistone, P.J., \& Dee, J.R. (2000). Conflict management strategies of principals in site-based managed schools. Journal of Educational Administration, 38(2), 142-158. 
Jehn, K. A., Northcraft, G. B., \& Neale, M. A. (1999). Why differences make a difference: A field study of diversity, conflict and performance in workgroups. Administrative science quarterly, 44(4), 741-763.

Kuo, M., Lin, F., Lin, C., \& Chen, F. (2014). A study on relationships among conflict management and school effectiveness. In 2014 International Conference on $e$ Education, e-Business and Information Management (ICEEIM 2014). Atlantis Press.

Labich, K. (1988). The 7 Keys to Business Leadership. Fortune, 118(9), 58.

Ma, Z., Lee, Y., \& Yu, K. H. (2008). Ten years of conflict management studies: themes, concepts and relationships. International Journal of Conflict Management.

McCarthy, M. E. (1981). Work Sharing Case Studies. WE Upjohn Institute for Employment Research, 300 South Westnedge Ave., Kalamazoo, MI 49007.

McNamara, C. (2007). Basics of conflict management. Adapted from the Field Guide to Leadership and Supervision.

Mitroff, I. (1998). Smart Thinking for Crazy Times: The Art of Solving the Right Problems. Berrett-Koehler Publishers, Inc., 450 Sansome Street, Suite 1200, San Francisco, CA 94111-3320.

Okotoni, O., \& Okotoni, A. (2003). Conflict management in secondary schools in Osun State, Nigeria. Nordic Journal of African Studies, 12(1), 23-38.

Onsarigo, B. (2007). Factors influencing conflicts in institutions of higher learning. Department of Sociology and Anthropology, Egerton University.

Owens, R. (1998), Organizational Behavior in Education, Allyn \& Bacon, Needham Heights, MA.

Pelled, L. H., Eisenhardt, K. M., \& Xin, K. R. (1999). Exploring the black box: An analysis of work group diversity, conflict and performance. Administrative science quarterly, 44(1), 1-28.

Pondy, L. R. (1969). Varieties of organizational conflict. Administrative Science Quarterly, 499-505.

Rahim, M. A. (2001) Managing conflict in organizations. $3^{\text {rd }}$ Edition, Quorum Books,

Rahim, M. A. (2002). Toward a theory of managing organizational conflict. International journal of conflict management, 13(3).

Rahim, M. A., Garrett, J. E., \& Buntzman, G. F. (1992). Ethics of managing interpersonal conflict in organizations. Journal of Business Ethics, 11(5-6), 423-432.

Ramani, K., \& Zhimin, L. (2010). A survey on conflict resolution mechanisms in public secondary schools: A case of Nairobi province, Kenya. Educational research and reviews, 5(5), 242.

Roemer, J. (1988). Free to Lose. Cambridge, MA: Harvard University Press. 
Schwartzman, R. (2013). Consequences of commodifying education. Academic Exchange Quarterly, 17(3), 1-7.

Tschannen-Moran, M., \& Hoy, W. (1998). Trust in schools: A conceptual and empirical analysis. Journal of Educational administration.

UNICEF. (1995). The United Nations International Children's Emergency Fund (UNICEF). A Report.

Weldon, E., \& Jehn, K. A. (1995). Examining cross-cultural differences in conflict management behavior: A strategy for future research. International Journal of Conflict Management.

Yang, J., \& Mossholder, K. W. (2004). Decoupling task and relationship conflict: The role of intragroup emotional processing. Journal of Organizational Behavior: The International Journal of Industrial, Occupational and Organizational Psychology and Behavior, 25(5), 589-605.

Yin, R. K. (2009). Case study research: Design and methods fourth edition. Los Angeles and London: SAGE. 